\title{
Social Media Marketing and Brand Loyalty: The Role of Brand Trust
}

\author{
Astrid PUSPANINGRUM ${ }^{1}$
}

Received: September 10, 2020 Revised: November 08, 2020 Accepted: November 16, 2020

\begin{abstract}
This study examines the relationship between social media marketing and brand loyalty through brand trust. Respondents were drawn from customers of McDonald's, Malang City, East Java Province, Indonesia. For this study, 130 questionnaires were distributed and data were analyzed using the Structure Equation Model (SEM) version 22 of the AMOS (Analysis of Moment Structure) application. The results showed that social media marketing had an impact on increasing McDonald's brand trust and brand loyalty. Brand trust influences brand loyalty and brand trust can mediate the influence of social media marketing on McDonald's brand loyalty. The findings prove that brand trust can mediate the effect of social media marketing on customer loyalty to McDonald's brand. These results can be explained by the fact that marketing strategies through social media marketing, such as making it easy for customers to get information related to McDonald's on social media, can contribute to customer trust and that trust is formed because McDonald's always pays attention to the quality of the products offered. Brand trust can mediate the influence of social media marketing on customer loyalty to McDonald's brand. This means that information related to McDonald's on social media is proportional to the quality of the product offered.
\end{abstract}

Keywords: Social Media Marketing, Brand Trust, Brand Loyalty

JEL Classification Code: M31, M37, L83

\section{Introduction}

Indonesian people, especially urban people, are starting to get interested and like fast food such as hamburgers, fried chicken, spaghetti, pizza, hot dogs, and many more. McDonald's, Kentucky Fried Chicken (KFC), New York Chicken are some brands that are well known to the public in Indonesia. An extraordinary development is especially experienced by McDonald's, which is a fast-food restaurant that offers a variety of fast food dishes. The food and drinks offered are also very varied, i.e., burgers, spaghetti, fried chicken, and so on, so that it will further pamper customers with the menu choices provided. Starting from a humble drive-in restaurant in Pasadena, McDonald's developed into a fast-food restaurant franchise with a presence in nearly every country in the world. McDonald's has even been able

\footnotetext{
${ }^{1}$ First Author and Corresponding Author. Management Department, Faculty of Economics and Business, Universitas Brawijaya, Indonesia [Postal Address: Jl. MT, Haryono 165, Malang, Jawa Timur, 65142, Indonesia] Email: astrid@ub.ac.id

(c) Copyright: The Author(s)

This is an Open Access article distributed under the terms of the Creative Commons Attribution Non-Commercial License (https://creativecommons.org/licenses/by-nc/4.0/) which permits unrestricted non-commercial use, distribution, and reproduction in any medium, provided the original work is properly cited.
}

to create a trend for fast-food restaurants and a new lifestyle among the global community.

These successes are of course not achieved easily. McDonald's marketing strategy is what makes the franchise able to survive and compete with other fast-food restaurants. However, the increasing number of fast-food restaurants that have sprung up makes the competition even tighter. This competition has also led McDonald's to differentiate itself from competitors. This condition requires McDonald's to constantly improve its marketing strategy. Marketing strategies carried out through social media marketing. According to William and Cothrell (2000), social media marketing (SMM) is a smart business marketing strategy being part of an online network. Social media is a form of business-to-consumer (B2C) that makes marketers quickly realize the value of social media marketing as a branding opportunity. Social media marketing is a tool that helps companies communicate with consumers in building brand loyalty outside of traditional methods (Erdogmus \& Cicek, 2012).

Social media is a tool that helps companies to build brand loyalty through networking, conversation, and building community (McKee, 2010). Social media users can participate through features on social media, which have the power to influence consumer decision-making 
processes in making purchases. The central role of social media marketing in making purchasing decisions is by talking about positive things to family and friends, which is often known as word-of- mouth (WOM). Research conducted by Fotis et al. (2012) and Valck et al. (2010) stated that virtual communities are an important network that will influence consumer behavior. Becker and Lee (2019) reveal that large companies have more social media ownership than small companies and large companies respond to social media posts at a greater frequency and faster than small companies.

Social media marketing is the most important tool in building brand loyalty. The relationship between social media marketing and brand loyalty according to Kotler and Keller (2008) brand loyalty can be conceptualized as the final dimension of consumer brand resonance symbolizing the customers ultimate relationship and level of identification with the brand. This is evidenced by empirical studies conducted by Erdogmus and Cicek (2012); Mehrabi et al. (2014); Bagaturia and Johson (2014); Khoa, (2020) that social media marketing influences brand loyalty. Different results are shown by Schivinski and Dabrowski (2015); Rumman and Alhadid (2014) who stated that company communication on social media does not affect brand loyalty. The inconsistent results of this study create a research gap.

Several studies have documented brand trust as a mediation of the influence of social media marketing on brand loyalty. Morgan and Hunt (1994) conceptualize trust when a group has the belief that the exchange partner has reliability and integrity. Trust is a condition that involves positive expectations about the motives of other parties related to a person in a risky situation (Boon \& Holmes, 1991). The results of the study conducted by Mosavi and Kenarehfard (2013a; 2013b); Khoa, (2020) concluded that social media marketing is about brand trust. Research that links brand trust with brand loyalty, as conducted by Ahmed (2014); Jha (2014); Etemadifard et al. (2016); Bastian (2014); Khoa, (2020); Wu, et al. (2020) show that brand trust has a significant positive effect on brand loyalty. Brand trust is an important factor in building brand loyalty, because to build consumer trust in social media related to the products or services offered, so that companies can build consumer emotion, this is as stated by Dam (2020) that brand trust contributes to the tendency of customers to behave towards attitudes towards a brand.

\section{Literature Review}

\subsection{Social Media Marketing}

Social media marketing is a tool that helps companies communicate with consumers in building brand loyalty outside of traditional methods (Jackson, 2011; Akhtar, 2011). Companies can promote products and services, provide support, and create an online community of brand fans through social media such as social networking sites, blogs, microblogging, online games, social bookmarking, news sites, and many more (Zarella, 2010; Kaplan \& Haenlein, 2009; Weinberg, 2009). Also, social media allows consumers to share information with their peers about the brands of products and services (Stileman, 2009; Mangold \& Foulds, 2009). Conversations between colleagues make the company provide an effective way to increase brand awareness, increase brand recognition, and are easy to remember, and can increase brand loyalty (Gunelius, 2011). Thus, it can be said that social media helps companies to build brand loyalty through networking, conversations, and building communities (McKee, 2010).

According to William (2000), social media marketing (SMM) is a smart business marketing strategy that is part of an online network. Social media is a form of businessto-consumer (B2C) that makes marketers quickly realize the value of social media marketing as a branding opportunity. The challenge is to get people to participate by giving reasons for joining, i.e., to share photos, debate the benefits of salt and meat as an important part of the diet, discuss business issues facing consumers, and how companies interact with customers via Facebook.

Social media is a strategic way of interacting with customers and finding what customers want. With social media, customers can show that they like a product or content through votes and comments. Through social media, consumers can get attention and provide social action. For example, Twitter is a social site designed to share short messages with others or to make "status updates". Facebook is a full-blown social networking site that allows you to share status updates, share photos from various activities. Through social media, it makes it easier to find new content such as news and activities. The application of social media in the company will assist the company is introducing its brand and products, as well as being used to post activities that have been carried out.

Evans and McKee (2010) show that $64 \%$ of marketers plan to increase their use of social media. Therefore social media marketing has become part of an organization's marketing strategy in an effort to reach a wider range of consumers. The social web has transformed traditional marketing communications. Traditional brand communication that was previously controlled and managed by brands and marketing managers has gradually led consumers to have an interest in making purchases. The rapid growth in the popularity of social media platforms in recent years has raised the question of whether this phenomenon has reduced marketers to controlling brand management (Berthon et al., 2012). In social media, knowledge about the influence of companies creates communication by shaping consumer perceptions of brands and the influence of online consumers from content created from brands is very important (Berthon et al., 2008; Christodoulides, 2009). 


\subsection{Brand Trust}

Brand trust is an important factor to help customers be loyal to the brand. Customer trust in a brand (brand trust), it is the brand's ability to be trusted (brand reliability), which comes from consumer confidence that the product can fulfill the promised value (brand intention), which itself is based on consumer confidence that the brand can prioritize consumer interests (Delgado \& Munuera, 2005). Trust is the most important factor in a brand that can increase or decrease the value of the brand itself, and make consumers have a sense of belonging to a brand. Moormal et al. (1992) stated that trust can influence consumers in buying a brand, meaning that a brand can create an emotional feeling with customers, while Delgado and Munuera (2005) state that brand trust is the ability of a brand to fulfill the interests of its consumers, so brand trust is a factor that can make consumers have an emotional bond with the company and make consumers loyal.

\subsection{Brand Loyalty}

According to Aaker (1997), brand loyalty is the main idea of a brand. This means that brand loyalty reflects the level of loyalty or consumer interest in a brand. Without loyalty, a brand is very vulnerable and easily replaced by other brands. When brand loyalty increases, the vulnerability of customer groups to competitors' attacks can be reduced. According to Schiffman and Kanuk (2009), brand loyalty is a consistent consumer preference to make purchases for the same brand on a specific product. So, brand loyalty is a strong commitment to subscribing to making purchases on brands consistently in the future.

Brand loyalty is the result of brand trust or a promise to build a highly valued connection (Morgan \& Hunt 1994; Chaudhuri \& Holbrook, 2001). Then, Oliver (1999) defines the concept of loyalty as a firmly held commitment to make repeat purchases of products/services consistently in the future, leading to repeat purchases of the same brand, even though there are situational influences that cause switching behavior.

Furthermore, it is said that brand loyalty is a reaction of dogmatic behavior in the buying process of a brand and causes a tendency towards certain brands in making decisions. This reaction is a function of the psychological process and one's subjectivity in dealing with the same product, so that customers often choose brands that are familiar, respectful, and confirm (Vazifehdoost et al., 2014). An economical way to increase brand loyalty is through social media. It can be said that social media helps companies to create brand loyalty through networking, conversation, and socializing. Information that comes from social media is indispensable in an increasingly competitive modern business. Therefore, companies use social media as a consulting tool to create content, features, and activities on social media which are expected to attract the attention and thoughts of consumers and make consumers loyal to the brand (Gordhamer, 2009).
So that by providing relevant content, it can cause consumers to experience an emotional bond with the brand which will cause consumers to be loyal.

\subsection{Hypothesis and Model Development}

Evans and McKee, (2010) show that $64 \%$ of marketers plan to increase their use of social media. Therefore, social media marketing has become part of an organization's marketing strategy in an effort to reach a wider range of consumers. Thus, social media marketing has become part of an organization's marketing strategy to reach a wider range of consumers (Evans \& McKee, 2010). In social media, knowledge about the influence of companies creates communication by shaping consumer perceptions of brands and the influence of online consumers from content created from brands is very important (Berthon et al., 2012; Christodoulides, 2009). The relationship between social media marketing and brand loyalty has been carried out by some researchers such as Erdogmus and Cicek (2012); Mehrabi et al., (2014); Bagaturia and Johson, (2014); Khoa, (2020). They show that social media marketing has a positive impact on increasing brand loyalty. Based on this research, the first hypothesis is proposed:

H1: Social media marketing has a significant positive effect on brand loyalty

Marketing in social media is considered an effective tool in developing relationships with customers (Choi et al., 2016). Also, these interactions will build trust and eliminate uncertainties that might prevent customers from engaging with brands (Khadim et al., 2018) and conducting online transactions (Chahal \& Rani, 2017). Tatar and ErenErdogmus (2016), Mosavi and Kenarehfard (2013a), and Khoa, (2020) in their research support the positive influence of social media marketing characterization on brand trust. Based on this research, the second hypothesis is proposed:

H2: Social media marketing has a significant positive effect on brand trust

Trust in social media attributes influence consumer behavior, trust is considered a mediator of the relationship between marketing activities in social media and behavioral intention (Kim and Park, 2013). Yoo and Donthu (2001) perceived the intention to make repurchases. Research that has been conducted by Laroche et al. (2013); Jha (2014); Etemadifard et al. (2016); Bastian (2014); Khoa, (2020); $\mathrm{Wu}$ et al. (2020) concluded that brand trust has a significant effect on brand loyalty. Based on this research, the third hypothesis is proposed:

H3: Brand trust has a significant positive effect on brand loyalty 


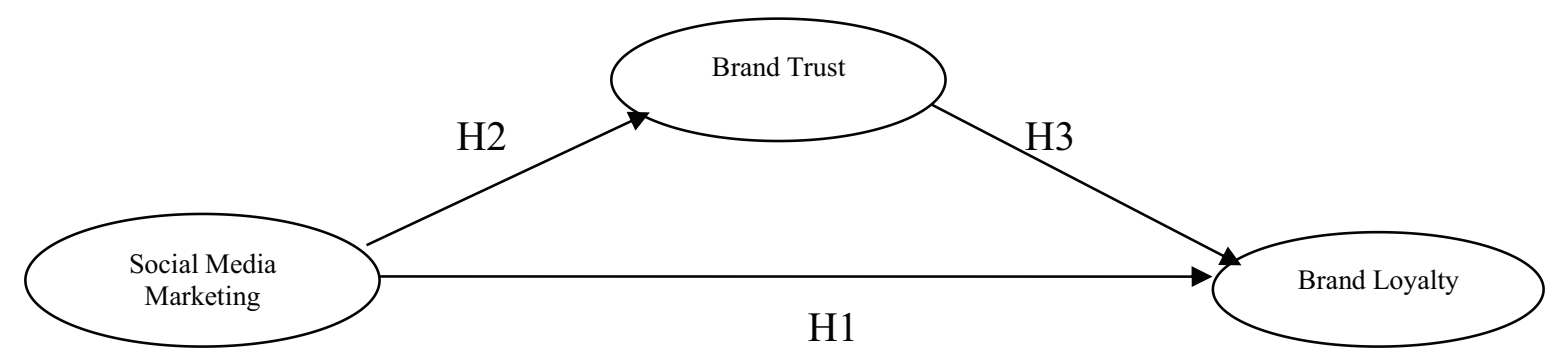

Figure 1: depicted the conceptual model constructed in this study

Previous research looked at the direct influence of social media marketing on brand loyalty, which has been studied by Erdogmus and Cicek (2012); Mehrabi et al. (2014), then the direct influence of social media marketing on brand trust was researched by Mosavi and Kenarehfard (2013a; 2013b); and the direct influence of brand trust on brand loyalty was studied by Laroche et al. (2014); Jha (2014); Efemadifard (2011); Bastian (2014), whereas in this study we want to see the indirect effect of social media marketing on brand loyalty through brand trust. Based on the concepts and results of previous research, the fourth hypothesis put forward is as follows:

H4: Brand trust mediates the influence of social media marketing on brand loyalty.

\section{Research Methods and Materials}

\subsection{Population and Sample}

The population of this study was McDonald's customers in Malang. This population is so large it cannot be known with certainty. According to Ferdinand (2006: 145), the sample size is determined by multiplying the number of indicators from five variables by $5-10$. Based on these provisions, the sample size used is $13 \times 10=130$ people.

After determining the number of samples as many as 130 people who were respondents in this study, then the sampling was carried out using a purposive sampling technique, namely, a sampling technique selecting subjects according to the criteria desired by the researcher. The research sample criteria are as follows:

1. Minimum age 18 years, at the age of 18 respondents are independent in providing answers because they are considered adults.

2. Decision-maker, meaning that the respondents selected are customers who make at least two purchases a month at McDonald's.

\subsection{Measurements}

Social media marketing variables are measured by five indicators in reference to Erdogmus and Cicek (2012), namely, advantageous campaigns, relevant content, popular content, various platforms (PV), and applications on social media (AOSM). Brand trust variable is measured by three indicators, namely, achieving result (AR), acting with integrity (AWI), and showing concern (DC), based on Bastian (2014), while brand loyalty is measured by five indicators, namely, behavior measures (BM), measuring switch cost (MSC), measuring satisfaction (MS), measuring liking brand (MLB), and measuring commitment (MC), based on Bastian (2014). Measurement of variables uses a 5-point Likert scale, from 1 'strongly disagree' to 5 'strongly agree'.

\subsection{Data Analysis}

The analysis technique in this research is Structural Equation Modeling (SEM). A three-step analysis was carried out to process the data. The first analysis is testing the suitability of the model through a review of the various goodness of fit criteria. The second stage conducting a direct effect hypothesis test, and the third stage conducting a mediation test, which is tested by the Sobel Test.

\section{Results and Discussion}

\subsection{Testing of Model Suitability}

At this stage, the suitability of the model is tested through a review of various goodness of fit criteria. Guidelines for model evaluation are used: X2-Chi-square statistic, where the model is considered good or satisfactory if the chisquare value is low. The smaller the $\mathrm{X} 2$ value, the better the model is, and accepted based on probability with a cut-off value of $\mathrm{P}>0.05$ or $\mathrm{P}<0.10$; The Root Mean Square Error of Approximation (RMSEA), which shows the goodness of fit, that can be expected if the model is estimated in the 
population (Hair, 1992: 138). The RMSEA value, which is less than or equal to 0.08 , is an index for the acceptance of a model that shows a close fit of the model based on the goodness of freedom; Goodness of Fit Index (GFI) is a non-statistical measure that ranges from 0 (poor fit) to 1.0 (perfect fit). High scores on this index indicate a "better fit"; Adjusted Goodness of Fit Index (AGFI), where the recommended level of acceptance is when AGFI has a value equal to or greater than $0.90 ; \mathrm{CMIN} / \mathrm{DF}$, is the Minimum Sample Discrepancy Function divided by the Degree of Freedom. CMIN/DF is nothing, but a chi-square statistic; $\mathrm{X} 2$ divided by its DF is called relative $\mathrm{X} 2$. If the relative $\mathrm{X} 2$ value is less than 2.0 or 3.0 , it is an indication of acceptable fit between the model and the data; Tucker Lewis index (TLI), an incremental index that compares a tested model against a baseline model, is a reference for acceptance of a model is $\geq 0.95$ (Ferdinand, 2002) and a value close to 1 indicates a very good fit and comparative Fit Index (CFI), which when it approaches 1, indicates the highest level of fit (Arbukle, 1997). The recommended value is CFI $\geq 0.95$. The results of the goodness of fit overall model test are given in the Figures and Tables below.

The analysis results related to the model feasibility index explain that the model produces good feasibility values. SEM analysis results, as outlined in Table 1.

The results of the Overall Goodness of Fit test are shown on Figure 2 and Table 1; it can be seen that all the criteria indicate that the model has met the cut-off value, therefore, the model can be categorized as suitable for use, so that it can be interpreted for further discussion.

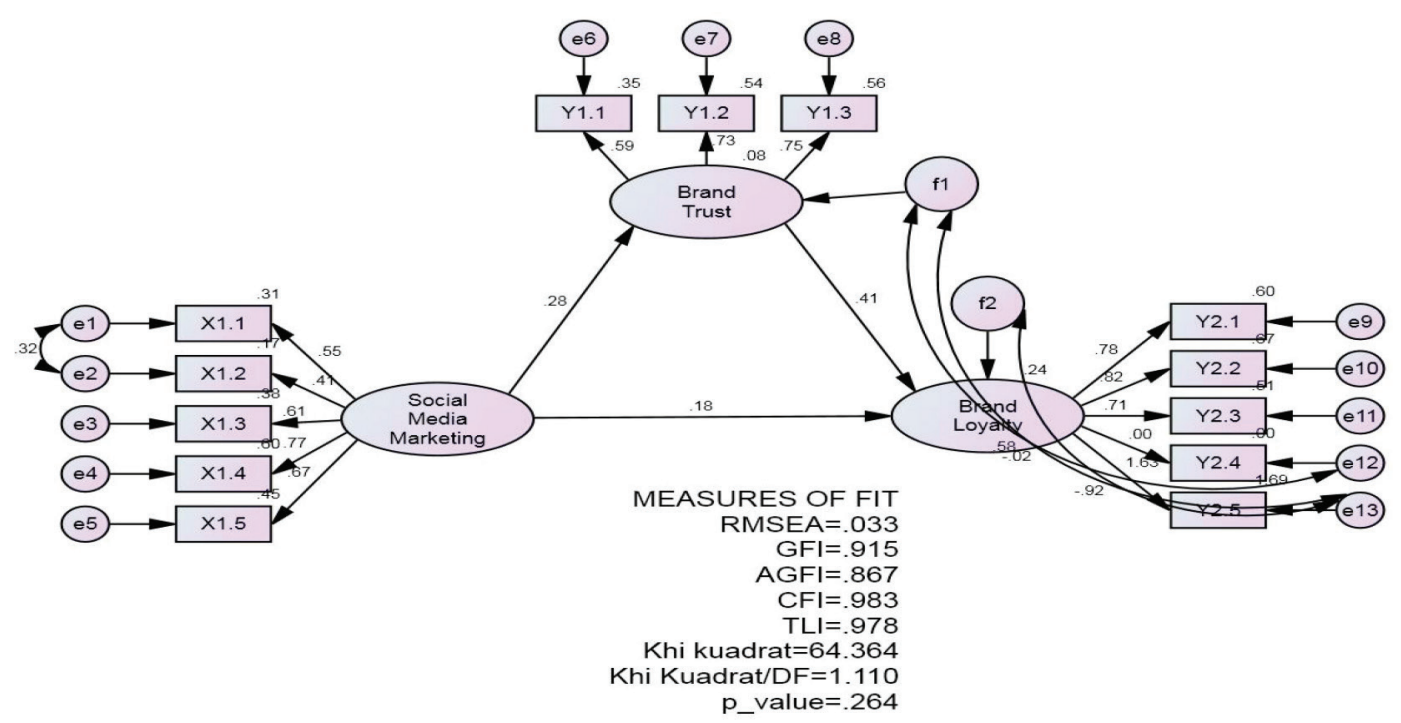

Figure 2: SEM Analysis Result Path Diagram

Table 1: Goodness Of Fit Overall Model Test Results

\begin{tabular}{|l|c|c|c|}
\hline Criteria & Cut-off value & Model Results & Mark \\
\hline Khi Quadrat & Kecil & 64.364 & Good Model \\
\hline p-value & $\geq 0.05$ & 0.364 & Good Model \\
\hline CMIN/DF & $\leq 2.00$ & 1.110 & Good Model \\
\hline GFI & $\geq 0.90$ & 0.915 & Model Marginal \\
\hline AGFI & $\geq 0.90$ & 0.867 & Good Model \\
\hline TLI & $\geq 0.95$ & 0.978 & Good Model \\
\hline CFI & $\geq 0.95$ & 0.983 & Good Model \\
\hline RMSEA & $\leq 0.08$ & 0.033 & \\
\hline
\end{tabular}




\subsection{Hypothesis Test}

The influence of social media marketing on brand trust resulted in an at-statistic value of 2.652 with a p-value of 0.008 . Because the p-value is smaller than the statistical significance at $\alpha=5 \%$, then social media marketing directly has a significant effect on brand trust, meaning that the better social media marketing, the higher consumer confidence in McDonald's brand. The effect of brand trust on brand loyalty produces a t-statistic value of 4,972 with a p-value of 0,000 . Because the $p$-value is smaller than the statistical significance at $\alpha=5 \%$, brand trust directly has a significant effect on brand loyalty, meaning that the higher the consumer trust in McDonald's brand, the stronger the customer loyalty to McDonald's brand. The influence of social media marketing on brand loyalty produces a t-statistic value of 2.329 with a p-value of 0.020 . Because the p-value is smaller than the statistical significance at $\alpha=5 \%$, then social media marketing directly has a significant effect on brand loyalty, meaning that the better social media marketing, the stronger customer loyalty to McDonald's brand.

The influence of social media marketing on brand loyalty through brand trust produces a t-statistic value of 2,336 with a p-value of 0.019. Because the p-value is smaller than the statistical significance at $\alpha=5 \%$, brand trust can mediate the influence of social media marketing on brand loyalty, meaning that the better social media marketing, the stronger customer trust will have an impact on increasing customer loyalty to McDonald's brand.

\subsection{Discussion}

Four research objectives are discussed in this study. The first objective is to determine the effect of social media marketing on brand trust. The second objective examines the influence of brand trust on brand loyalty. The third objective looks at the influence of social media marketing on brand loyalty, and the fourth objective is to examine the mediating effect of brand trust. The following sections discuss the findings of this study.

Social media marketing is a tool that helps companies communicate with consumers in building brand loyalty outside of traditional methods (Jackson, 2011; Akhtar, 2011).
Companies can promote products and services, provide support, and create an online community of brand fans through social media such as social networking sites, blogs, microblogging, online games, social bookmarking, news sites, and many more (Zarella, 2010; Kaplan \& Haenlein, 2009; Weinberg, 2009). Also, social media allows consumers to share information with their peers about the brands of products and services (Stileman, 2009; Mangold \& Foulds, 2009).

This study found evidence that social media marketing has an impact on increasing customer trust and loyalty toward McDonald's brand. These results can be explained by the fact that marketing strategies through social media marketing such as making it easy for customers to get information related to McDonald's on social media, such as blogs, Facebook, and Twitter can increase customer trust in the McDonald's brand, this is because this trust arises. After all, McDonald's always pays attention to product quality that is offered. Theoretically, these findings support previous research by Tatar and Eren-Erdogmus (2016); Mosavi and Kenarehfard (2013a), that social media marketing has a positive impact on increasing brand trust.

Regarding the findings that prove that social media marketing has an impact on increasing customer loyalty, this can be explained by the fact that marketing strategies through social media marketing, such as making it easy for customers to get information related to McDonald's on social media like blogs, Facebook and Twitter, have an impact on increasing customer loyalty shown by measuring with cost, such as even though the price is higher, will still choose McDonald's over other fast food. Theoretically, these findings support previous research by Erdogmus and Cicek (2012); Mehrabi et al., (2014); Bagaturia and Johson, (2014) that social media marketing has a positive impact on increasing brand loyalty.

Regarding testing the effect of brand trust on brand loyalty, the results of the study concluded that increasing brand trust has an impact on increasing customer loyalty to McDonald's brand. These results can be explained by the fact that the increase in customer loyalty to the McDonald's brand is shown by still choosing McDonald's over other fast-food restaurants, even though the price offered by McDonald's is higher because the element of customer trust in the McDonald's brand and that trust arises.

Table 2: Results of Weight Regression Analysis

\begin{tabular}{|l|l|c|c|c|}
\hline Hypothesis & \multicolumn{1}{|c|}{ Path } & t-statistic & p-value & Mark \\
\hline $\mathrm{H} 1$ & $\mathrm{SMM} \rightarrow \mathrm{BT}$ & 2.652 & 0.008 & Supported \\
\hline $\mathrm{H} 2$ & $\mathrm{BT} \rightarrow \mathrm{BL}$ & 4.972 & 0.000 & Supported \\
\hline $\mathrm{H} 3$ & $\mathrm{SMM} \rightarrow \mathrm{BL}$ & 2.329 & 0.020 & Supported \\
\hline $\mathrm{H} 4$ & $\mathrm{SMM} \rightarrow \mathrm{BT} \rightarrow \mathrm{BL}$ & 2,336 & 0.019 & Supported \\
\hline
\end{tabular}


After all, McDonald's always pays attention to the quality of the products offered. Theoretically, these findings support previous research by Laroche et al. (2013); Jha (2014); Etemadifard et al. (2013); Bastian (2014); Khoa, (2020); $\mathrm{Wu}$ et al. (2020). They concluded that brand trust has a significant effect on brand loyalty.

Based on the results of medical tests, these findings prove that brand trust can mediate the effect of social media marketing on customer loyalty to McDonald's brand. These results can be explained by the fact that marketing strategies through social media marketing, such as making it easy for customers to get information related to McDonald's on social media like blogs, Facebook, and Twitter, can contribute to customer trust and that trust is formed because McDonald's always pays attention to the quality of the products offered. This means that information related to McDonald's on social media, such as blogs, Facebook, and Twitter, is proportional to the quality of the product offered. When customer trust in the McDonald's brand is high, customer loyalty to the brand will increase as shown by still choosing McDonald's over other fast-food restaurants, even though the price offered by McDonald's is higher. This supports the study put forward by Mosavi and Kenarehfard $(2013 a ; 2013 b)$ that there is an effect of social media marketing on brand trust and a direct influence of brand trust on brand loyalty, which was researched by Laroche et al. (2014); Jha (2014); Efemadifard (2011); Bastian (2014).

\section{Conclusions}

Social media marketing has an impact on increasing customer trust and loyalty towards McDonald's brand. Marketing strategies through social media marketing, such as making it easy for customers to get information related to McDonald's on social media like blogs, Facebook, and Twitter, can increase customer trust in the McDonald's brand because this trust arises. After all, McDonald's always pays attention to the quality of the products offered and makes improvements against loyalty shown by the fact that, even though the price is higher, consumers will still choose McDonald's over other fastfood alternatives.

Increased customer loyalty to the McDonald's brand is shown by continuing to choose McDonald's over other fast-food restaurants, even though the price offered by McDonald's is higher, because of the element of customer trust in McDonald's brand's and this trust arises because McDonald's always pays attention to the quality of the products offered.

Brand trust can mediate the influence of social media marketing on customer loyalty to McDonald's brand. This means that information related to McDonald's on social media, such as blogs, Facebook, and Twitter, is proportional to the quality of the product offered. When customer trust in the McDonald's brand is high, customer loyalty to the brand will increase as shown by still choosing McDonald's over other fast-food restaurants, even though the price offered by McDonald's is higher.

\section{References}

Aaker, J. L. (1997). Dimensions of brand personality. Journal of Marketing Research, 34(3), 347-356. Doi.10.2307/3151897

Ahmed, M. A., \& Zahid, Z. (2014). Role of social media marketing to enhance CRM and brand equity in terms of purchase intention. Asian Journal of Management Research, 4(3), 533-549.

Rumman, A. H. A., \& Alhadid, A. Y. (2014). The Impact of Social Media Marketing on Brand Equity: An Empirical Study on Mobile Service Provides in Jordan. Society of Interdisciplinary Business Research, 3(1), 315-326.

Bagaturia, G., \& Johson, M. (2014). The Impact of Social Media in Marketing Management. Journal of Business, 3(1), 5-13.

Bastian, D. A. (2014). The Influence of Brand Image and Brand Trust on Brand Loyalty ADES PT. Ade Alfindo Putra Setia. Jurnal Manajemen Pemasaran Petra, 2(1), 1-9.

Becker, K., \& Lee, J. W. (2019). Organizational Usage of Social Media for Corporate Reputation Management. Journal of Asian Finance, Economics and Business, 6(1), 231-240. http://doi. org/10.13106/jafeb.2019.vol6.no1.231

Berthon, P. R., Pitt, L. F., Plangger, K., \& Shapiro, D. (2012), Marketing meets Web 2.0, social media, and creative consumers: implications for international marketing strategy, Business Horizons, 55(3), 261-271. doi.org/10.1108/WHATT03-2015-0014

Boon, S., \& Holmes, J. (1991). The Dynamics of Interpersonal Trust: Resolving Uncertainity in the Face of Risk. In: R. Hinde \& J. Gorebel (Eds.), Cooperation and Prosocial Behaviour (pp. 190-211). Cambridge, UK: Cambridge University Press.

Choi, E. K., Fowler, D., Goh, B., \& Yuan, J. (2016). Social media marketing: Applying the uses and gratification theory in the hotel industry. Journal of Hospitality Marketing and Management, 25, 771-796. doi:10.1080/19368623.2016.1100 102

Chaudhuri, A., \& Holbrook, M. B. (2001). The Chain of Effects from Brand Trust and Brand Affect to Brand Performance: The Role of Brand Loyalty. Journal of Marketing, 65(2), 81-93.

Christodoulides, G. (2009). Branding in the post-internet era, Marketing Theory, 9(1), 141-144. doi:10.1509/jmkg.65.2.81. 18255

Dam, T. C. (2020). Influence of Brand Trust, Perceived Value on Brand Preference and Purchase Intention. Journal of Asian Finance, Economics and Business, 7(10), 939-947. https://doi. org/10.13106/jafeb.2020.vol7.no10.939 
Delgado, B. E., \& Munuera, A. J. L. (2005). Does Brand Trust Matter to Brand Equity? Journal of Product and Brand Management, 14(3), 87-196. doi.10.1108/10610420510601058

Erdogmus, I., \& Cicek, M. (2012). The impact of social media marketing on brand loyalty. Procedia - Social and Behavioral Sciences, 58, 1353-1360. doi.org/10.1016/j. sbspro.2012.09.1119

Evans, D., \& McKee, J. (2010). Social Media Marketing: The Next Generation of Business Engagement. Hoboken, NJ: John Wiley and Sons.

Etemadifard, M., Kafashpoor, A., \& Zendehdel, A. (2016). The Effect of Brand Communication and Service Quality in the Creation of Brand Loyalty through Brand Trust (Case Study: Samsung's Representatives Company in Mashhad City). International Journal of Advanced Studies in Humanities and Social Science, 5(4), 336-346.

Fotis, J., Buhalis, D., \& Rossides N. (2012). Social media use and impact during the holiday travel planning process. In: M. Fuchs, F. Ricci, \& L. Cantoni (Eds.), Information and Communication Technologies in Tourism (pp. 13-24). Cham, Switzerland: Springer.

Gunelius, S. (2011). 30 minute Social Media Marketing: Step by Step Techniques to Spread the Words about your Business. New York, NY: McGraw-Hill.

Jha, B. (2014). Social Media, Brand Community, User generated comments and Brand Loyalty: Study of Indian Youth. IOSR Journal of Business and Management, 16(10), 122-131.

Kaplan, A. M.. \& Haenlein, M. (2009). The Fairyland of Second Life: Virtual Social Worlds and How to Use Them. Business Horizons, 52(6), 563-572.doi. 10.1016/j.bushor.2009.07.002

Khoa, B. T. (2020). The Antecedents of Relationship Marketing and Customer Loyalty: A Case of the Designed Fashion Product. Journal of Asian Finance, Economics and Business, 7(2), 195-204.

Kotler, P., \& Keller. K. L. (2009). Marketing Management $\left(13^{\text {th }}\right.$ ed.). Upper Saddle River, NJ: Pearson Prentice Hall.

Mangold, E., \& Foulds, G. (2009). Social Media: The New Hybrid Element of The Promotion Mix. Business Horizons, 52, 357365. doi.org/10.1016/j.bushor.2009.03.002

McKee, S. (2010). Creative B2b Branding (No, Really): Building a Creative Brand in a Business World. Oxford, UK: Goodfellow Publishers.

Mehrabi, A., Islami, H., \& Aghajani, M. (2014). The Effect of Social Media Marketing on Customers' Brand Loyalty. International Journal of Academic Research in Business and Social Sciences, 4(8), 480-495. doi. 10.6007/IJARBSS/v4-i8/1124

Morgan, R. M., \& Hunt, S. D. (1994). The Commitment-Trust Theory of Relationship Marketing. Journal of Marketing, 58(3), 20-38. doi. 10.2307/1252308.
Moorman, C., Gerald, Z. \& Rohit, D (1992). Relationships Between Providers and Users of Market Research: The Dynamics of Trust Within and Between Organizations. Journal of Marketing Research, 29(3), 314-328. doi 10.2307/3172742

Mosavi, S. A., \& Kenarehfard, M. (2013). The Effect of Value creation practices on brand trust and brand loyalty: Case study of Apple Iphone cell phone, Shiraz, Iran. Prime Journal of Business Administration and Management, 3(9), 1182-1189.

Mosavi, S. A., \& Kenarehfard, M. (2013). The Impact of Value Creation Practices on Brand Trust and Loyalty in a Samsung Galaxy Online Brand Community in Iran. IJMM Winter, 8(2), 75-84.

Oliver, R. (1999). Whence Consumer Loyalty?" Journal of Marketing, 63, 33-44. Doi. 10.2307/1252099

Schiffman, L. G., \& Kanuk L. L. (2009). Customer Behavior. Upper Saddle River, NJ: Prentice-Hall International, Inc.

Schivinski, B., \& Dabrowski, D. (2013). The Impact of Brand Communication on Brand Equity Dimensions and Brand Purchase Intention Through Facebook. GUT Faculty of Management and Economics, 4, 1-24.

Schivinski, B., \& Dabrowski, D. (2015). The impact of brand communication on brand equity through Facebook. Journal of Research in Interactive Marketing, 9(1), 31-53. doi. org/10.1108/JRIM-02-2014-0007

Stilema, P. (2009). To What Extent Has Social Media Change the Relationship Between Brand and Consumer. Dissertation, Bucks New University.

Valck, D. K., Langerak, F., Verhoefz, P. C., \& Verlegh, P. W. J. (2007). Satisfaction with Virtual Communities of Interest: Effect on Members' Visit Frequency. British Journal of Management, 18, 241-256. Doi. 10.1111/j.14678551.2006.00499.x

Williams, L., \& Cothrell, J. (2000). Four smart ways to run online communities. Sloan Management Review, 41(4), 81-91.

Weinberg, T. (2009). The New Community Rules: Marketing on the Social Web (1 $1^{\text {st }}$ ed.). Sebastopol, CA: O'Reilly Media.

Wu, W. Y., Do, T. Y., Nguyen, P. T., Anridho, N. A., \& Vu, M. Q. (2020). An Integrated Framework of Customer-based Brand Equity and Theory of Planned Behavior: A Meta-analysis Approach. Journal of Asian Finance, Economics and Business, 7(8), 371-381. https://doi.org/10.13106/jafeb.2020.vol7.no8.371

Vazifehdoost, H., Rahnama, A., \& Mousavian, S. J. (2014). Evaluation of the Influence of Fashion Involvement, Personality Characteristics, Tendency to Hedonic Consumption and Store Environment on Fashion-Oriented Impulse Buying. Mediterranean Journal of Social Sciences, 5(16), 223. doi 10.5901/mjss.2014.v5n16p223

Zarella, D. (2010). The Social Media Marketing Book. Sebastopol, CA: O’Reilly Media Inc. 